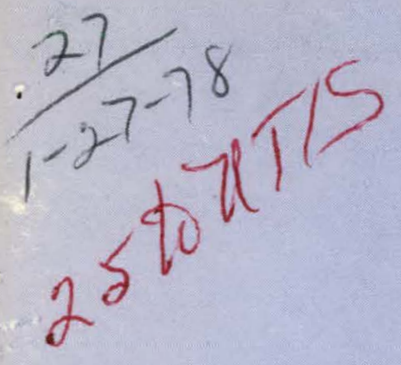

Dist. Category UC- 4

Hydrogen Gas from Cured RTV Silicones

Lester C. Myers

DEVELOPMENT DIVISION

OCTOBER 1977 Whenth

Process Development

Endeavor No. 101

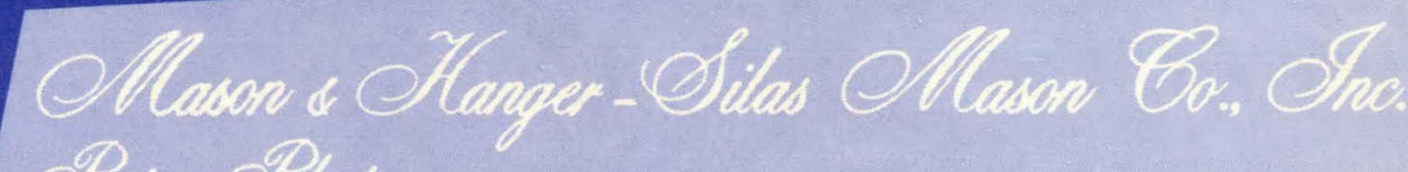

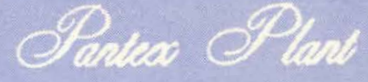 \\ P. O BOX 30020
AMARILLO. TEXAS 79177 \\ 806-335-1581 \\ ENEREY RESEARCH ANO OEVELOPAENT, ADMINISTRATION under
}




\section{DISCLAIMER}

This report was prepared as an account of work sponsored by an agency of the United States Government. Neither the United States Government nor any agency Thereof, nor any of their employees, makes any warranty, express or implied, or assumes any legal liability or responsibility for the accuracy, completeness, or usefulness of any information, apparatus, product, or process disclosed, or represents that its use would not infringe privately owned rights. Reference herein to any specific commercial product, process, or service by trade name, trademark, manufacturer, or otherwise does not necessarily constitute or imply its endorsement, recommendation, or favoring by the United States Government or any agency thereof. The views and opinions of authors expressed herein do not necessarily state or reflect those of the United States Government or any agency thereof. 


\section{DISCLAIMER}

Portions of this document may be illegible in electronic image products. Images are produced from the best available original document. 


\section{NOTICE}

This report was prepared as an account of work sponsored by the United States Government. Neither the United States nor the United States Energy Research and Development Administration, nor their employees, nor any of their contractors, subcontractors, or their employees, makes any warranty, express or implied, or assumes any legal liability or responsibility for the accuracy, completeness or usefulness of any information, apparatus, product or process disclosed, or represents that its use would not infringe privately-owned rights.

Printed in the United States of America

Available from

National Technical Information Service

U. S. Department of Commerce

5285 Port Royal Road

Springfield, VA 22161

Price: Printed Copy $\$ 4.00$; Microfiche $\$ 3.00$ 


\title{
HYDROGEN GAS FROM CURED RTV SILICONES
}

Lester C. Myers

DEVELOPMENT DIVISION

Process Development Endeavor No. 101

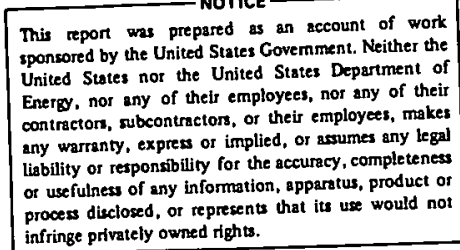

This report wess prepared as an account of work sponsored by the United States Covernment. Neither the Eneror nor any of their employees, nor any of their contractors, subcontractors, or their employees, makes any warranty, express or implied, or assomes, any hes or usefulness of any information, apparatus, product or infringe privately owned rights.

\begin{abstract}
Eight different RTV silicones were sealed in containers and after preselected times the amount of hydrogen in the containers was determined. The silicone samples were conditioned at $80 \mathrm{C}$ in a $100 \% \mathrm{RH}$ air atmosphere and at $23 \mathrm{C}$ in a dry air atmosphere.

The amount of gas from duplicate samples varied considerably. The cause of these variations was investigated and it was determined that humidity in a helium atmosphere produced the maximum hydrogen, and the amount of hydrogen is less if oxygen is present in the atmosphere.
\end{abstract}

\section{INTRODUCTION}

Los Alamos Scientific Laboratory (LASL) requested that Mason \& Hanger investigate the hydrogen gas from cured RTV silicone potting material.

The materials investigated were:

1. Dow Corning 93-119

2. Dow Corning 93=120

3. Dow Corning 95-077

4. Sylgard 184

5. Sylgard 186

6. General Electric 664

7. General Electric 6153

8. General Electric 6152

These materials are classed as addition curing silicones and they nomilly consist of a two part kit. The "resin" part contains a linear dimethylpolysiloxane (DMPS) with reactive vinyl groups and some form of a platinum catalyst. The second "catalyst" part contains a crosslinker such as polymethylhydrosiloxane (PMHS) with active hydrogen sites (see Fig. 1).

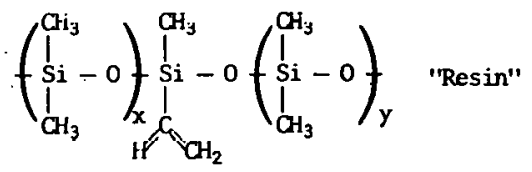

$$
\begin{aligned}
& +
\end{aligned}
$$

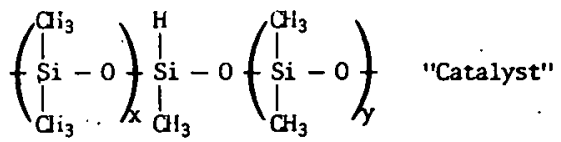

$$
\begin{aligned}
& \text {. } \downarrow \text { Hcat and Platinum Catalyst }
\end{aligned}
$$

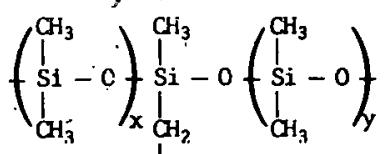

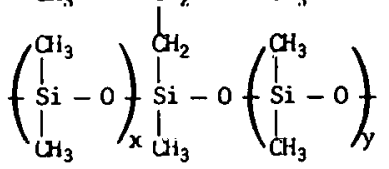

Fig. 1. The Crosslinking Reaction Between a Viny' 1 Croup and an Active Hydrogen of a Two Component Silicone Rubber System 
If a portion of the active hydrogen sites do not react with vinyl groups these sites would then be subject to hydrolysis and hydrogen would be produced.

\section{EXPERIMENTAL}

A standard test was developed to determine the amount of hydrogen produced and the approximate rate of hydrogen evolution. This was accomplished by sealing silicone samples in a container with an air atmosphere and a supply of water.

Three $44.5 \mathrm{~mm}$ diameter by $3.17 \mathrm{~mm}$ thick disks ( $\sim 15$ grams) were placed in each container. These disks were placed on an aluminum cylinder in the container with stainless steel screen wire between the samples to : allow good air circulation around the samples (see Fig. 2).

Three containers of each silicone sample were prepared and one gram of water was added to two of the containers. The three containers were sealed and the two containing water were cooled with liquid nitrogen to freeze the water while being evacuated and leak checked. The containers were backfilled with air to $26.6 \mathrm{kPa}$ and the two containers with water were stored at $80 \mathrm{C}$. The "dry" container was stored at $23 \mathrm{C}$.

At the end of 7, 50, 125 and 200 days, the two containers with water were removed from storage, cooled with liquid nitrogen and their atmosphere removed and fractionated to separate the hydrogen from the air. The volume of hydrogen was measured and each sample analyzed by a mass spectrometer to assure that the hydrogen was fractionated from the air. After analysis at 7, 50 and 125 day periods the containers were refilled with air and returned to the $80 \mathrm{C}$ storage. The $23 \mathrm{C}$

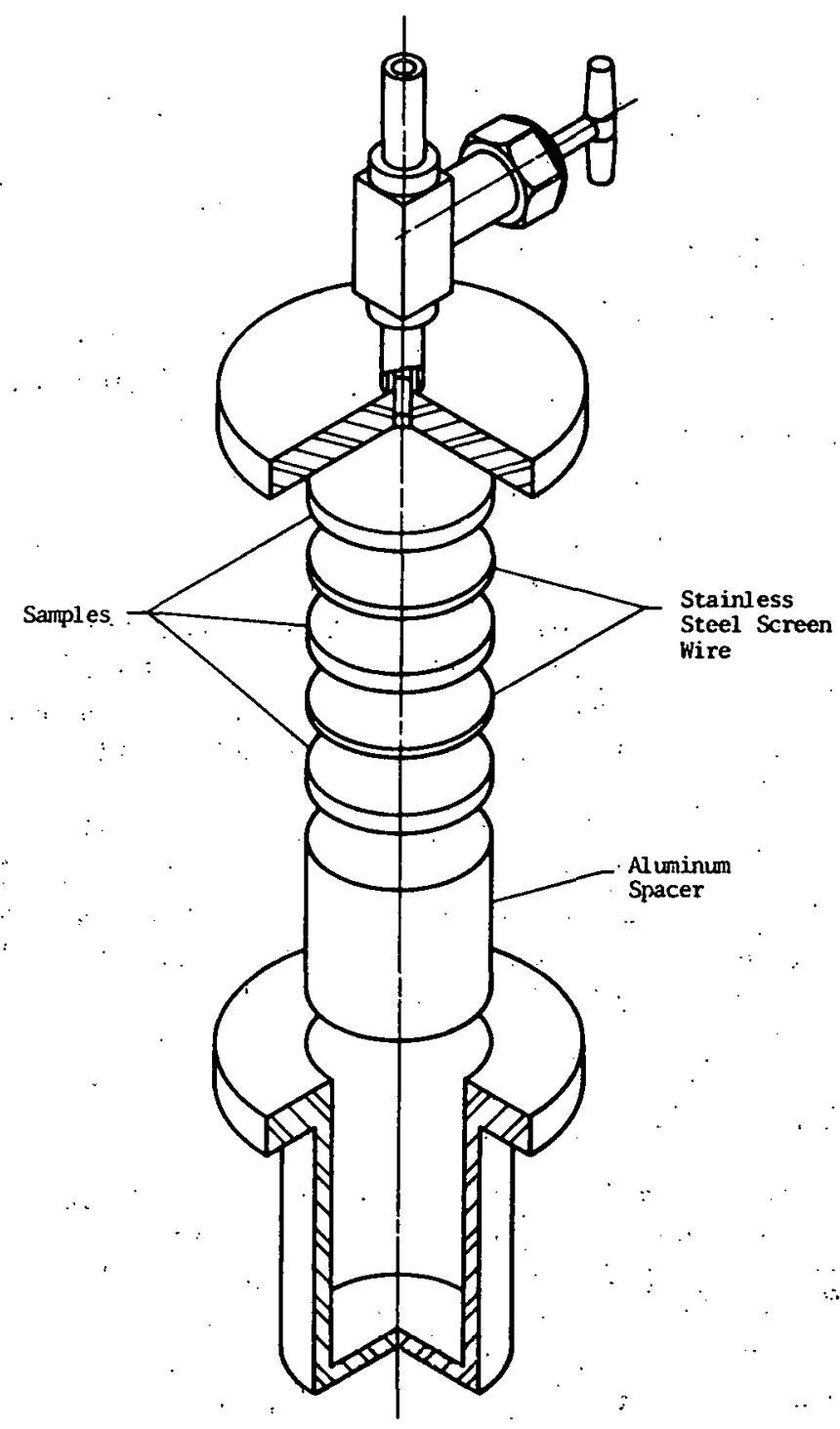

Fig. 2. Test Assembly used to Measure the Hydrogen Gas for Various Silicone Rubbers

samples were analyzed for hydrogen after 200 days. The data are given in Table I and plots of the $80 \mathrm{C}$ results are shown in Figs. 3 through 10. These data show a considerable amount of variation in the volume of hydrogen evolved by supposedly duplicate samples. The plots indicate an initial rate (in the first 7 to 10 days) followed by a much slower rate. If hydrolysis of the active hydrogen is the only mechanism for hydrogen evolution the rate should approach zero but this does not appear to be the case at least over the time period studied. 
Table I. Hydrogen Gas from RTV Silicones

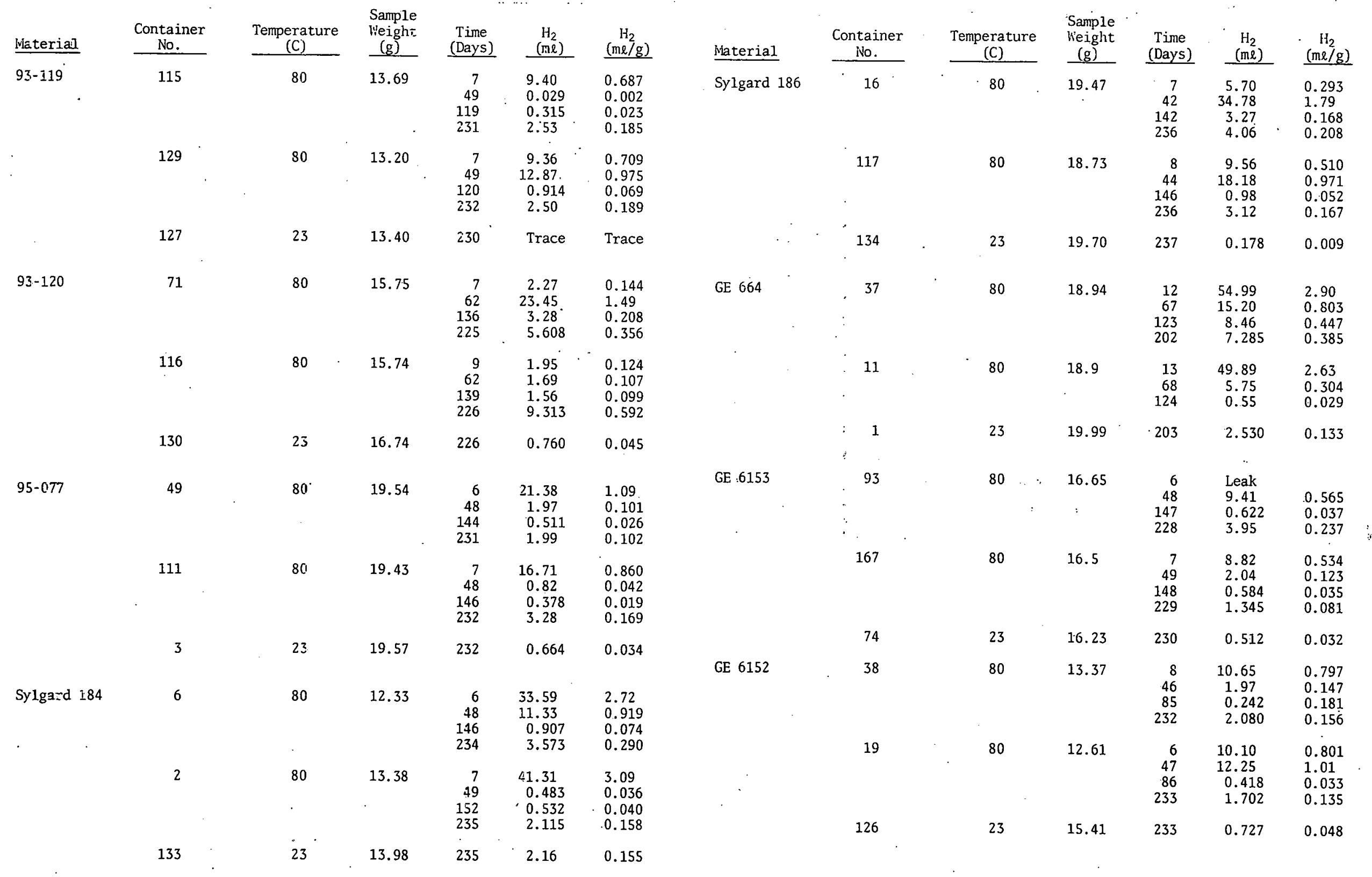


○ TS No. 115 at $80 \mathrm{C}$

- IS No. 129 at $80 \mathrm{C}$

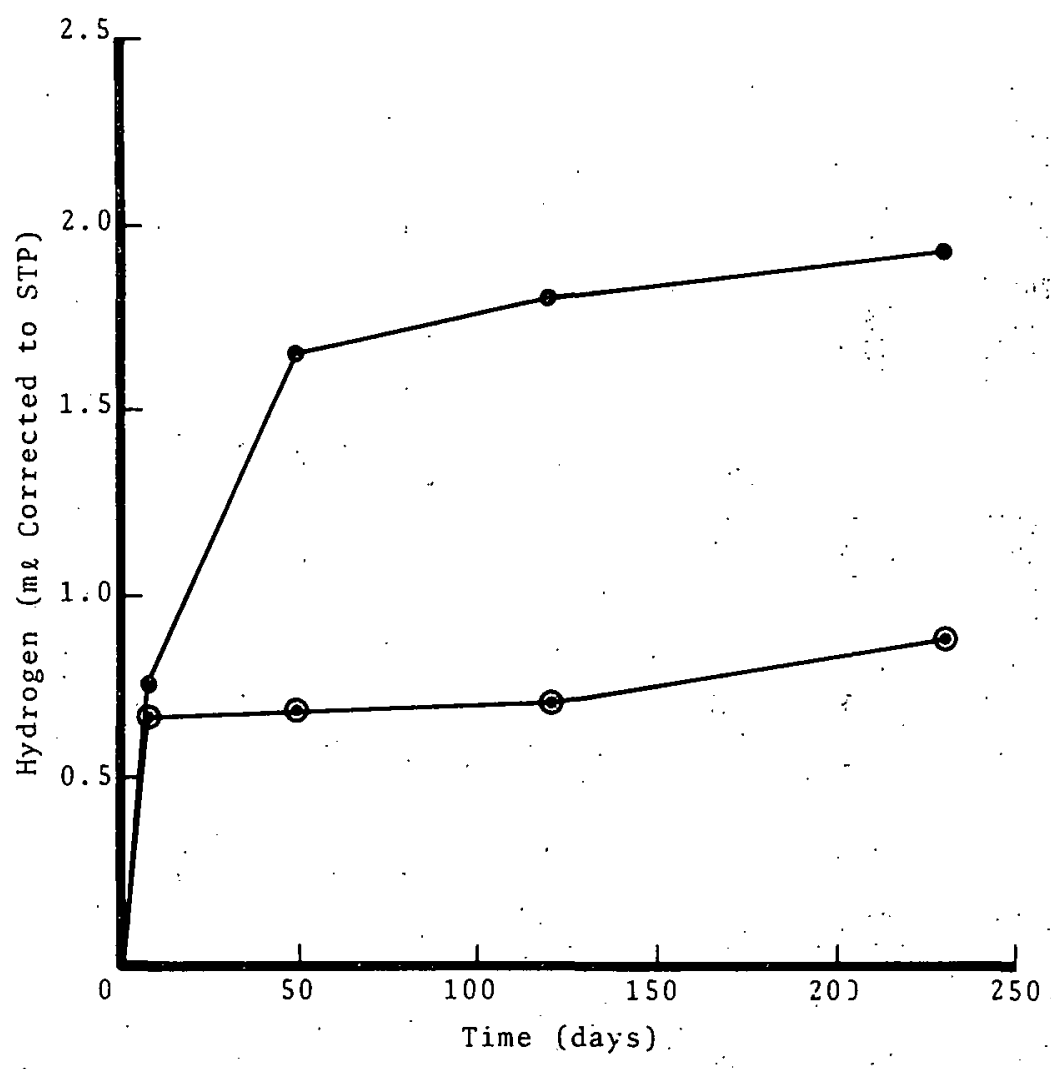

Fig. 3. Hydrogen Gas from Dow Corning 93-119

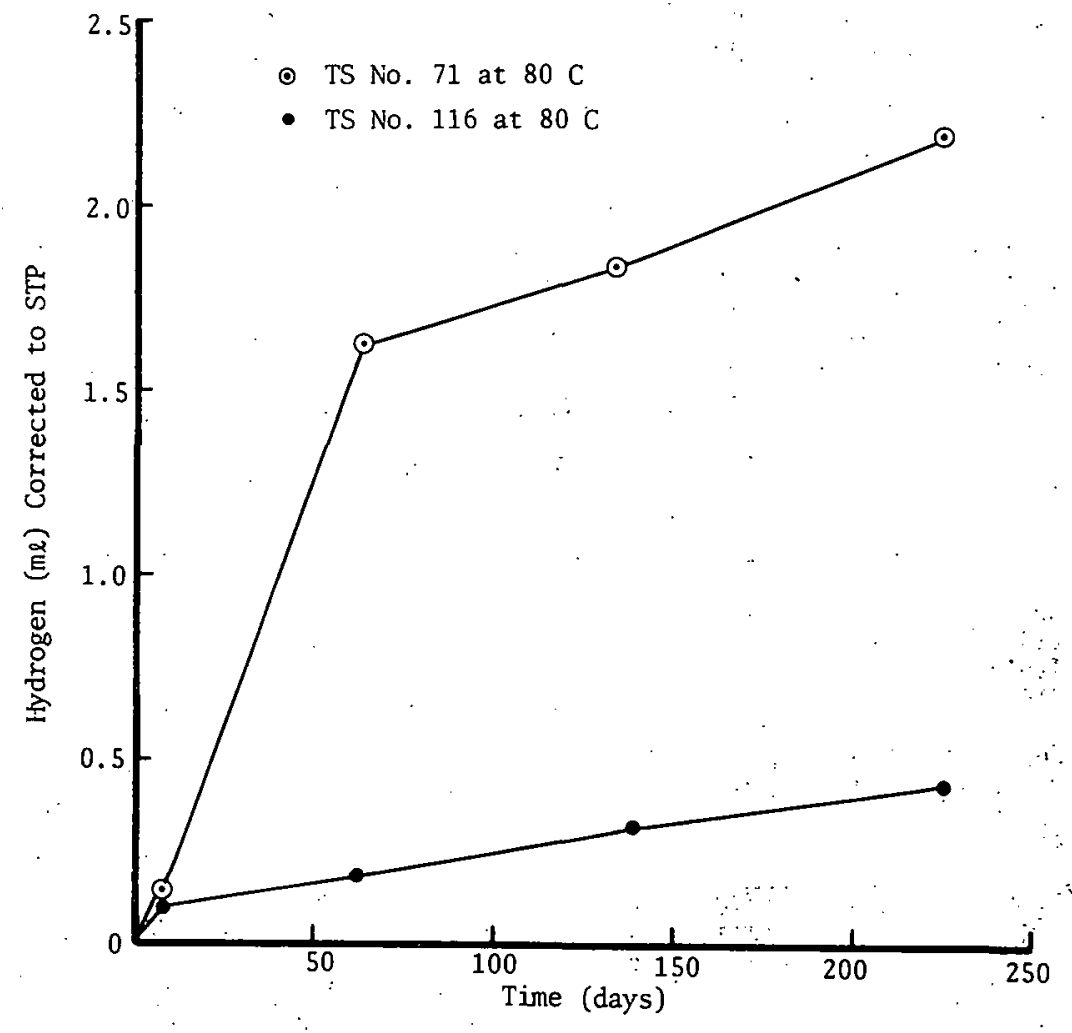

Fig. 4. Hydrogen Gas From Dow Corning 93-120 
O TS No. 49 at $80 \mathrm{C}$

- TS No. 111 at $.80 \mathrm{C}$

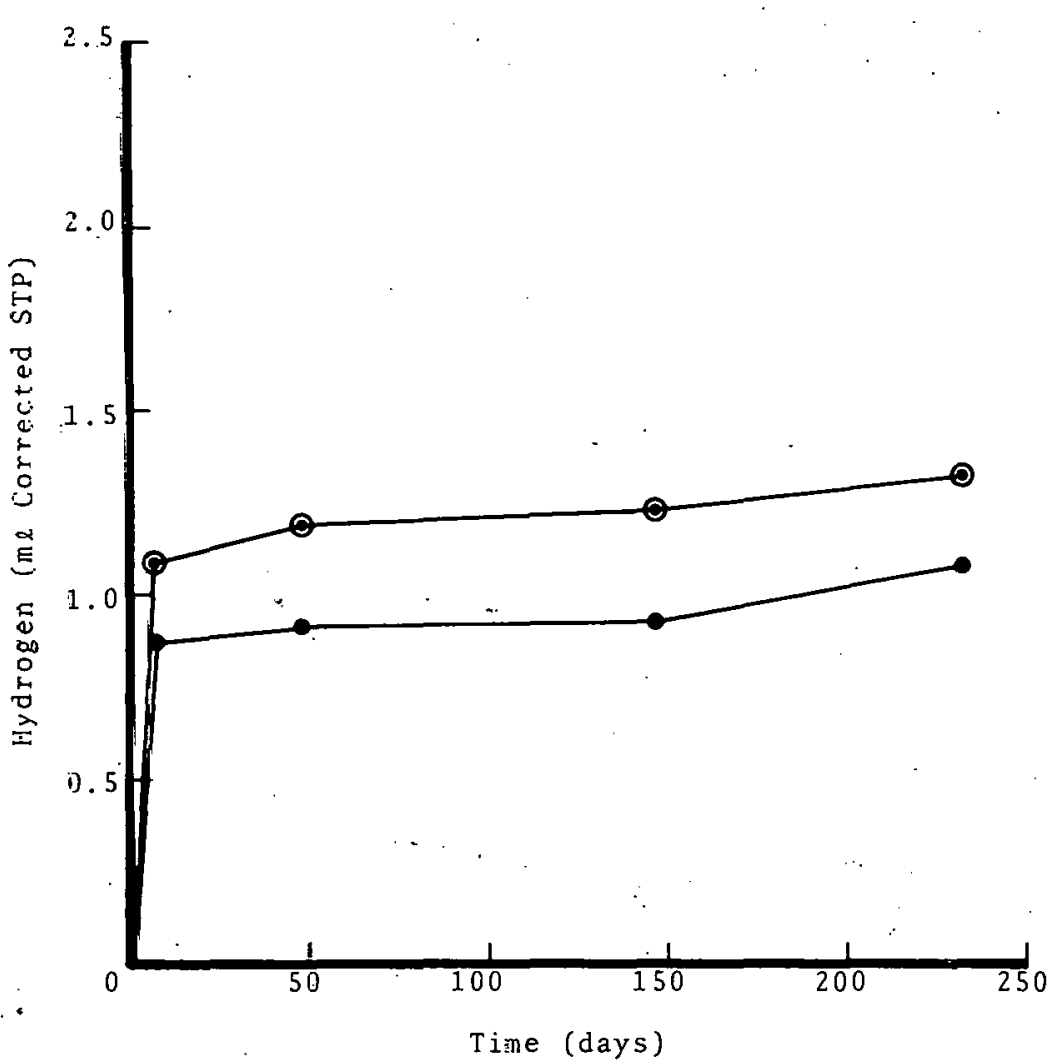

Fig. S. Hydrogen Gas from Dow corning 95-075
O TS No. 6 at $80 \mathrm{C}$

- TS No. 2 at $80 . C$

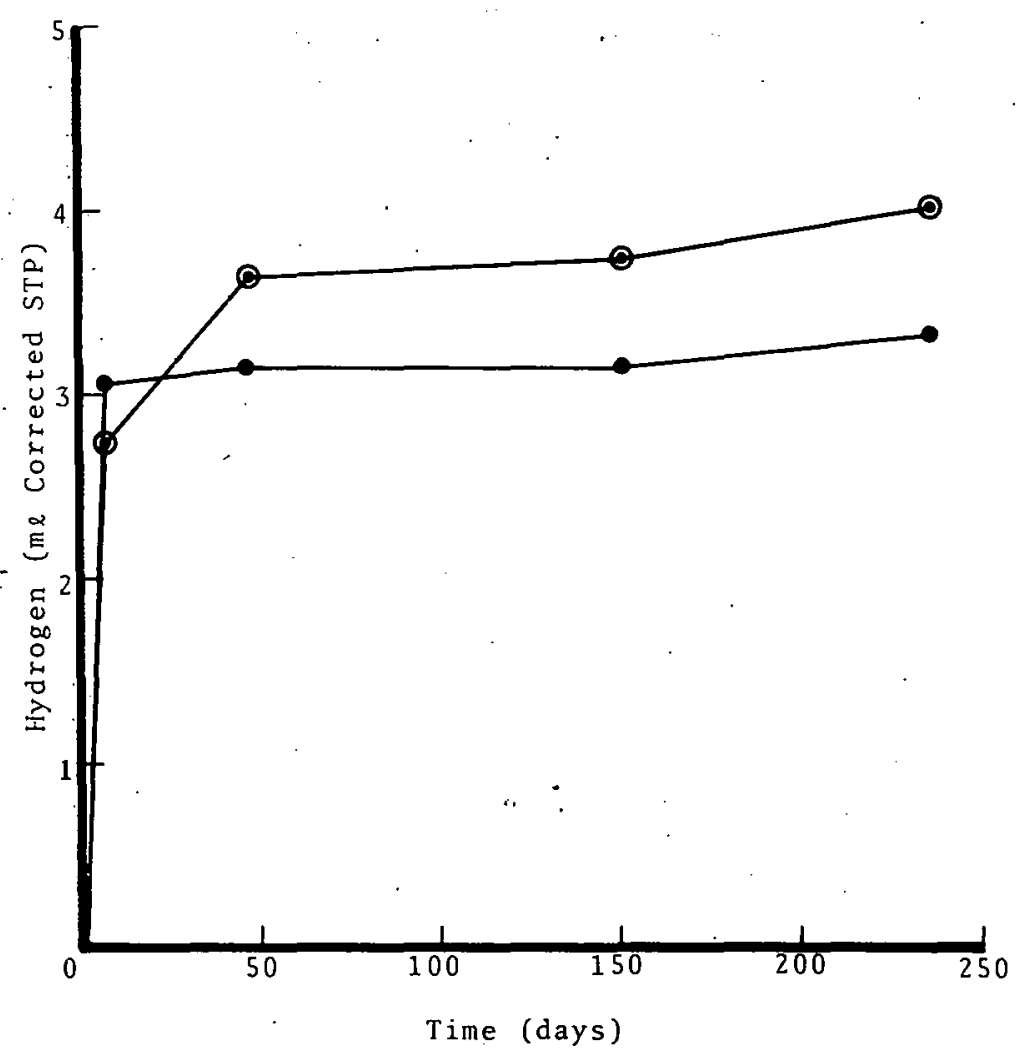

Fig. 6. Hydrogen Gas from Sylgard 184 
- TS No. 16 at 80 C

- TS No. 117 at $80 \mathrm{C}$

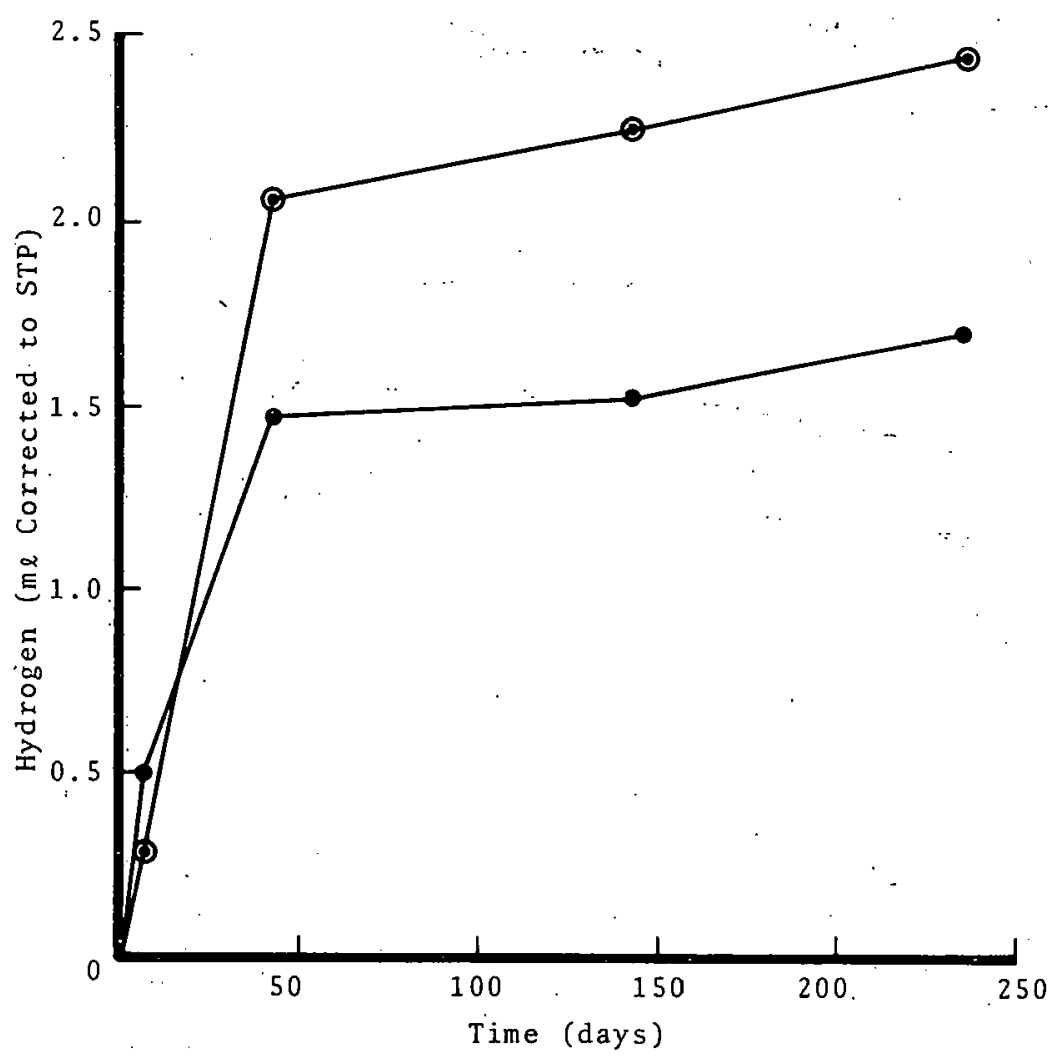

Fig. 7. Hydrogen Gas from Dow Corning Sylgard 186
- TS No. 37 at $80 \mathrm{C}$

- TS No. 11 at $80 \mathrm{C}$

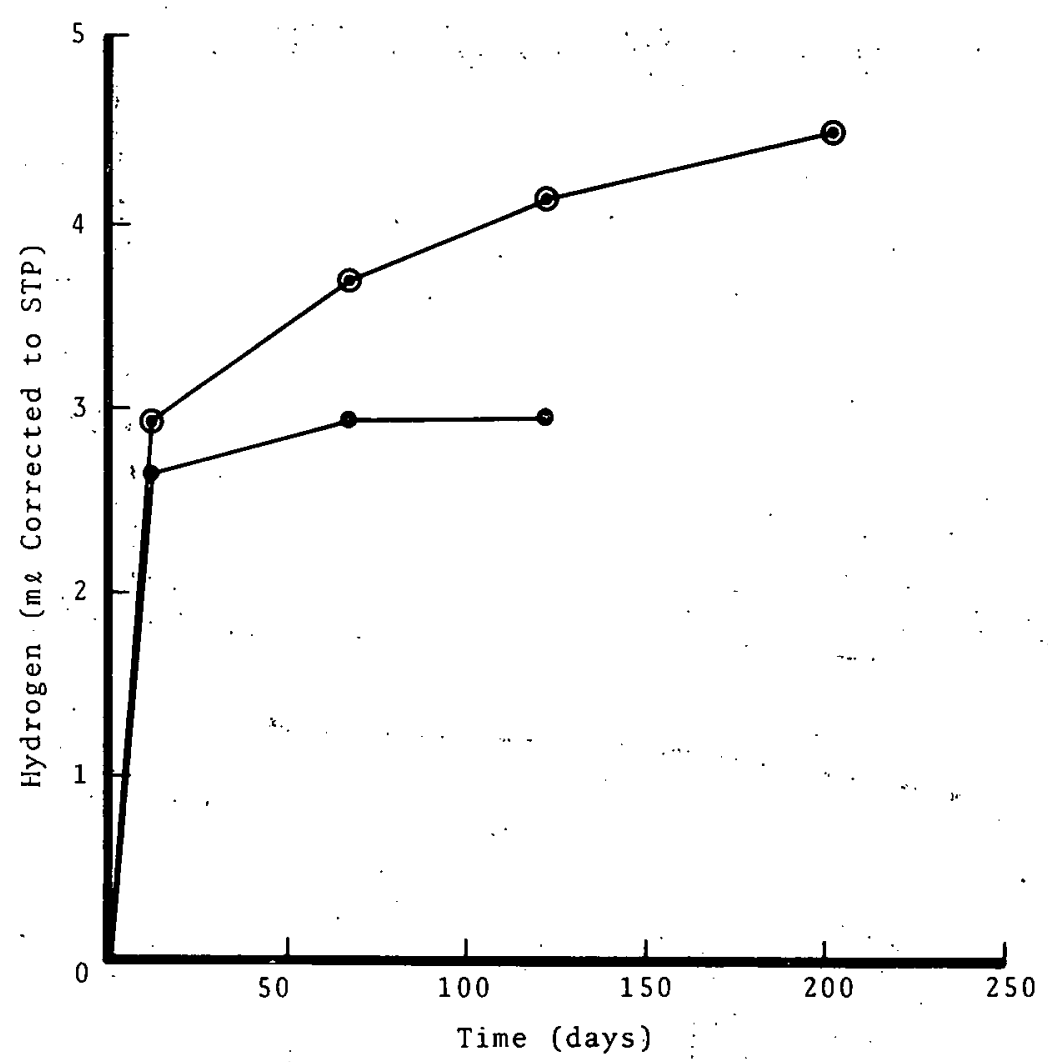

Fig. 8. Hydrogen Gas from General Electric 664 
- Is No. 32 at 80 E

- IS No. 167 at $80 \mathrm{C}$

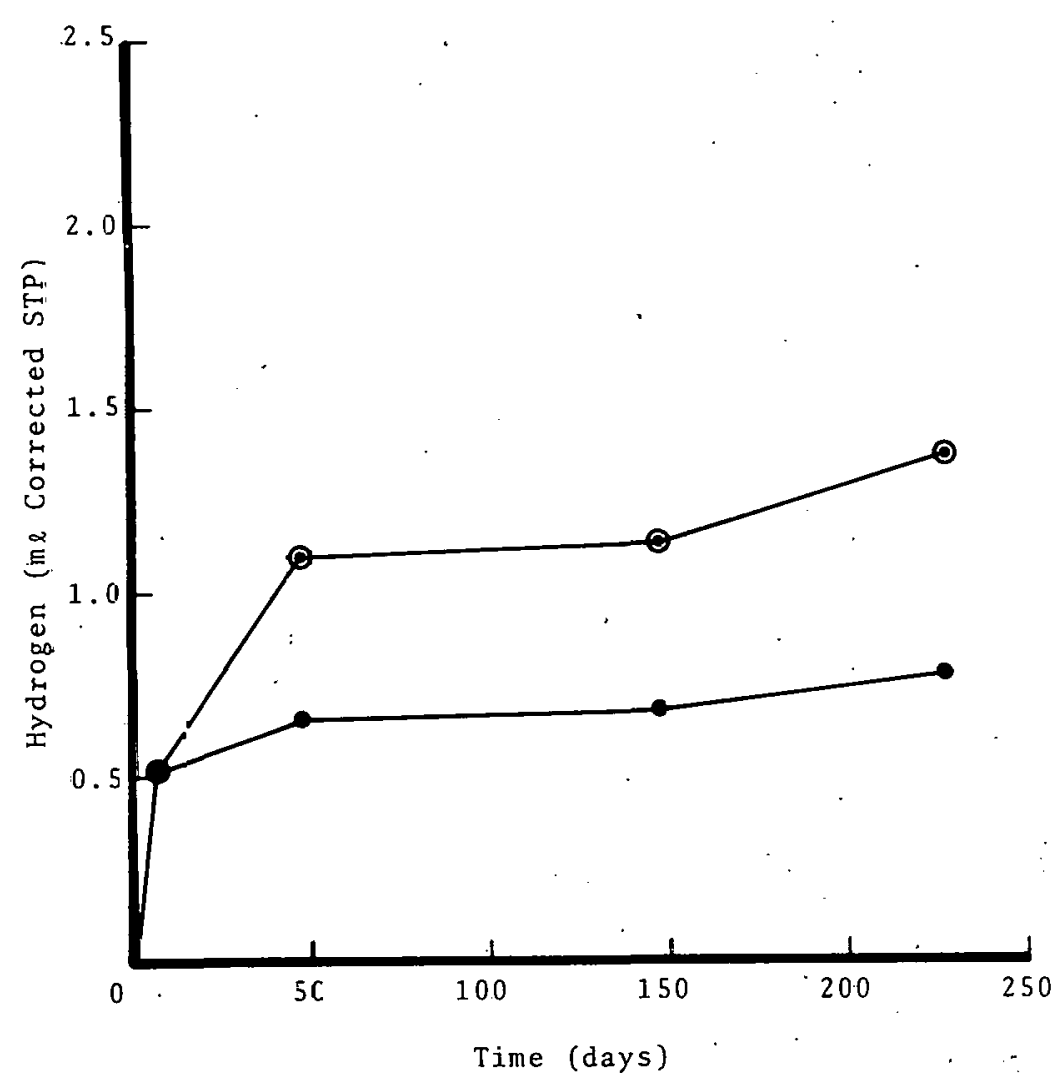

Fig. 9:. Hydroger. Gas from General Electric 6153
O TS No. 38 at $80 \mathrm{C}$

- TS NO.. 19 at $80 \mathrm{C}$

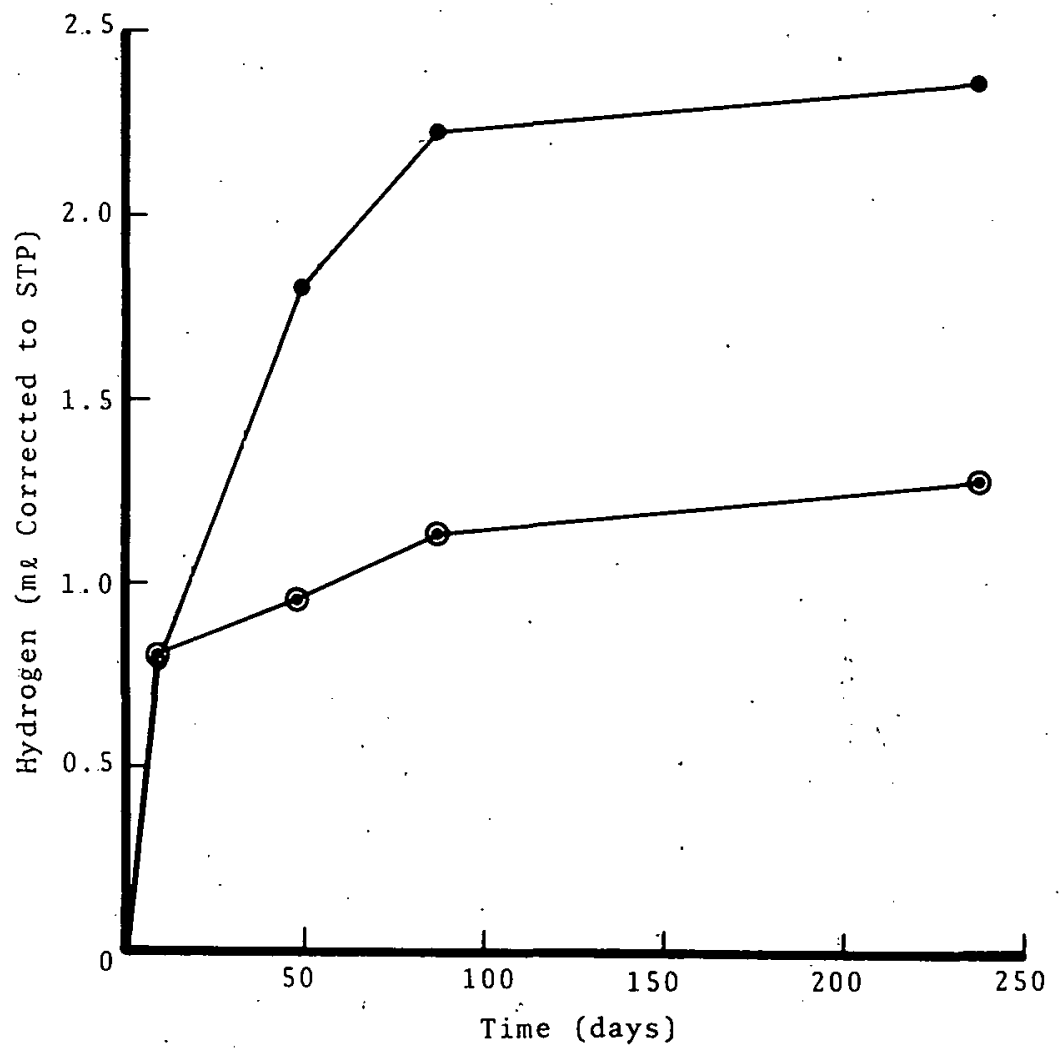

Fig. 10: Hydrogen Gas from General Electric 6152 
The maximum quantity of hydrogen evolved for each material is shown in Table II.

Table II. Total Hydrogen Evolved from Several Silicones

(Hydrogen Evolved at $80 \mathrm{C}$ in $\mathrm{m} \ell / \mathrm{g}$ Corrected to STP)

\begin{tabular}{|c|c|c|}
\hline Sample & $\begin{array}{r}\text { Time } \\
\text { Days } \\
\end{array}$ & $\begin{array}{c}\mathrm{H}_{2} \\
(\mathrm{~m} \ell / \mathrm{g}) \\
\end{array}$ \\
\hline DC $93-119$ & 232 & 1.94 \\
\hline DC $93-120$ & 225 & 2.20 \\
\hline DC 95-077 & 231 & 1.32 \\
\hline Sylgard 184 & . $\quad 234$ & 4.00 \\
\hline Sylgard 186 & 236 & $2: 45$ \\
\hline GE 664 & 202 & 4.54 \\
\hline GE 6153 & 228 & 1.37 \\
\hline GE 6152 & 232 & 2.36 \\
\hline
\end{tabular}

The reason for variations between samples was investigated and the following determinations were made.

1. Analysis of the atmosphere in the containers showed no oxygen. The oxygen had been consumed by the sample.

2. The free volume of the containers were different so the samples contained different amounts of. oxygen.

A preliminary: investigation was made to determine the effect of both oxygen and water on Sylgard 184. .

Duplicate assemblies were made with each of the following atmospheres:

1. Helium

2. Helium and Water

3. Helium/Oxygen/Neon

4. Helium/Oxygen/Neon and Water
Since it was not possible to match the free volumes of the containers, a special mixture of helium, oxygen, and neon $(73 / 17 / 10)$ was prepared. By determining the amount of neon at the end of the test, the amount of oxygen originally in the container could be calculated.

These samples were analyzed after 40 days at $70 \mathrm{C}$ for oxygen and hydrogen. These data are given in Table III.

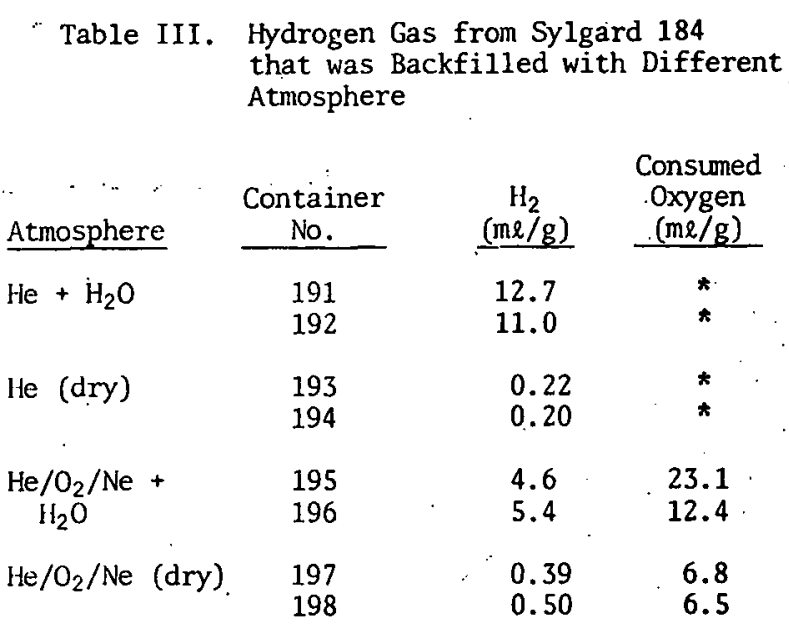

*Containeä only helium.

Comparison of the helium and helium/ water samples shows that water increased the amount of hydrogen. Comparison of the helium/water and helium/oxygen/neon/water samples shows that oxygen reduces the amount of hydrogen gas.

Essentially all of the oxygen was consumed in the samples containing the helium/oxygen/neon mixture.

An additional test was conducted to determine if water was consumed with atmospheres of helium and helium/oxygen/neon by sealing a sample of Sylgard 184 in a container 
with a hydrometer probe. The samples were conditioned at $70 \mathrm{C}$ for approximately one month and in both cases the dew point decreased with time.

\section{CONCLUSIONS}

There are at least two mechanisms that effect the amount of hydrogen gas present in the containers. Tests are planned to determine rates for:

1. Water Consumption

2. Oxygen Consumption

3. Hydrogen Evolution

With these data it should be possible to define the parameters for. a standard test which will give reproducible results. 
ALO

V. C. Vespe, Director

Weapons Development Division

R. R. Fredlund, Jr., Director

Classification \& Technical Information

Mound Lab

Director of Explosives

SLL

C. S. Selvage - Org. 8180

LLL

G. L. Dittman (10 Copies)

Attn: R. J. Woodworth

C. T. Brockett, Technical Information Dept.

LASL

E. H. Eyster - WX-DO

R. N. Rogers, Attn: F. B. Baker - WX-2

J. Aragon - WX-3

Report Library - 1SU-4

SLA

B. E. Arthur - Org. 1570

J. C. Crawford - Org. 2500/D. H. Andersion Org. 2510

J. C. King - Org. 2300/C. B. McCampbel1 Org. 2310

Central Technical Files - Org. 3141

UK

Jack Kirkham

Atomic Weapons Research Establishment

Aldermaston, Reading, England
$\underline{\mathrm{PX}}$

Division Manager, Mfg. Engineering

Division Manager, Quality

Division Manager, Development (2 copies)

B. H. Carr, E\&TC

Technical Library

Circulation Copy:

(1) Area Manager, DOE/AAO

(2) Division Manager, Manufacturing M\&्षH

Circulation Copy:

(1) C. R. Poole

(2) Plant Manager

(3) M\&్ષ-SM Co., Inc., Lexington, KY 